\title{
Metabolism of a New Antiallergic Agent, Emedastine Difumarate, in Human
}

\author{
Tsukasa HAmada and Norio Awata \\ Pharmaceuticals Research Center, Kanebo, Ltd., 5-90, \\ Tomobuchi-cho 1-chome, Miyakojima-ku, Osaka 534, Japan
}

Key words : Emedastine difumarate, 1-(2-Ethoxyethyl)-2-(hexahydro4-methyl-1H-1,4-diazepin-1-yl)-1H-benzimidazole difumarate, Antiallergic agent, Metabolism, Excretion, Urine, Human

\begin{abstract}
Summary
The metabolism of emedastine difumarate(KG-2413) after oral administration in human was studied. In human urine, 5-hydroxy-and 6-hydroxyemedastine and their conjugated metabolites were found as major metabolites and emedastine corresponding to $3.6 \%$ of dose was also excreted. Moreover 5hydroxy- and 6-hydroxy-5'-oxoemedastine, and emedastine $\mathrm{N}$-oxide were found as minor metabolites. The sum of urinary excretion ratio of emedastine and its metabolites was about $44 \%$ for $24 \mathrm{~h}$ after dosing. Taking urinary excretion ratio and plasma concentration of emedastine into consideration, the extent of bioavailability of emedastine difumarate in human might be similar to that in guinea pigs. However, the metabolic pattern in human was similar to that in rats, in which 5-hydroxy- and 6-hydroxyemedastine were urinary major metabolites and emedastine $N$-oxide was minor metabolites.
\end{abstract}




\section{Introduction}

Emedastine difumarate $(\mathrm{KG}-2413)$ is a new benzimidazole derivative with strong antihistaminic and antiallergic activities, and has lower toxicity in animals compared with other known antiallergic drugs such as ketotifen and chlorpheniramine ${ }^{1)}$. The chemical structure is shown in Fig. 1.

Absorption, distribution, metabolism and excretion of emedastine difumarate in animals have been already studied in detail by using ${ }^{14} \mathrm{C}$-labelled or non-labelled materials. ${ }^{14} \mathrm{C}$-Emedastine difumarate was absorbed rapidly and almost completely after oral dosing $^{2)}$. The distribution into each tissues of the radioactive parent drug and/or its metabolites was rapid and high, except for that into central nervous system ${ }^{3)}$. The excretion was also performed rapidly, and the radioactivity more than 95\% of dose was excreted into the urine and feces by $24 \mathrm{~h}$ after dosing ${ }^{2}$. While the absolute bioavailability in guinea pigs was about $50 \%$, that in rats and dogs was lower than $5 \%$, and it was considered that the pronounced interspecies differences were mainly due to the first pass effect ${ }^{4)}$. Emedastine was metabolized mainly in the liver, and the main pathways of biotransformation were aromatic hydroxylation in the benzimidazole ring, $N$-oxidation, $N$-demethylation and $\alpha$-carbon oxidation (lactam formation) in the 1,4 -diazepine ring and $O$-deethylation in the $N$-ethoxyethyl side chain ${ }^{5 \sim 7}$. Interspecies differences in the urinary excretion ratio of emedastine and its metabolites were observed in rats, guinea pigs and dogs, and it was shown that the differences were partially caused by the formation and reduction

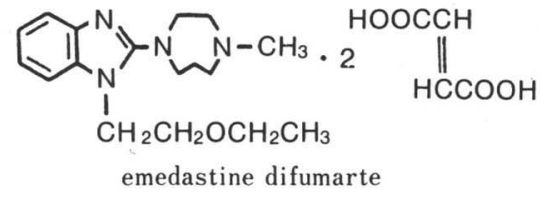

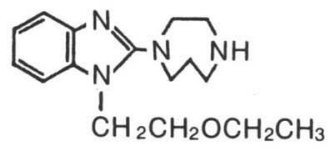

demethylemedastine<smiles>CN1CCN(c2nc3ccccc3n2CCO)CC1</smiles><smiles>CCOCCN1CCN(C)CC1c1nc2ccccc2n1C</smiles>

emedastine $\mathrm{N}$-oxide<smiles>CCOCCN1CCN(C)CC1c1nc2ccc(O)cc2n1C</smiles>

6-hydroxyemedastine<smiles>CCOCCN1CCN(C)CC1c1nc2cc(O)ccc2n1C</smiles>
5 -hydroxyemedastine<smiles>CCOC(=O)CN(CCN1CCN(C)CC1)c1nc2ccc(O)cc2n1C</smiles>

6-hydroxy-5'-oxoemedastine<smiles>CCOC(=O)CN(CCN1CCN(C)CC1)c1nc2cc(O)ccc2n1C</smiles>

5-hydroxy-5'-oxoemedastine

Fig. 1 Chemical structure of emedastine difumarate and its metabolites 
of emedastine $\mathrm{N}^{-}$oxide $^{7)}$. There were pronounced interspecies differences in the plasma protein binding of emedastine with about $80 \%$ in guinea pigs and about $40 \%$ in rats and $\operatorname{dogs}^{8)}$. The interspecies differences in the distribution volume were observed, and it was shown that the differences caused by the plasma protein binding ${ }^{9)}$.

We have developed the methods for determination of emedastine in body fluids by capillary gas chromatography (GC method) ${ }^{10)}$ and radioreceptor assay ${ }^{11 \sim 13)}$ in order to clarify the pharmacokinetics of emedastine difumarate in human. By using those methods the plasma concentrations and urinary excretion ratio of unchanged emedastine were measured ${ }^{14)}$. However, the metabolic fate of emedastine difumarate in human has not been clarified. The objective of this study is to investigate the metabolism of emedastine difumarate in human and to compare with that in the experimental animals.

\section{Experimental}

Materials - The powder of emedastine difumarate was identical to that used in the study of the determination method of emedastine ${ }^{13)}$. The authentic compounds, 1-(2-ethoxyethyl)-2-(hexahydro-1 $H$-1, 4-diazepin-1-yl)-1H-benzimidazole (demethylemedastine), 1(2-hydroxyethyl)-2-(hexahydro-4-methyl-1 H-1,4-diazepin-1-yl)-1H-benzimidazole (desethylemedastine), 1-(2-ethoxyethyl)-2-(hexahydro-4-methyl-1 $H-1,4$-diazepin-1-yl)- $1 H^{-}$-ben-

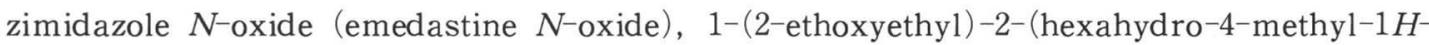
1, 4-diazepin-1-yl)-5-hydroxy-1 H-benzimidazole (5-hydroxyemedastine), 1-(2-ethoxyethyl)2-(hexahydro-4-methyl-1 H-1,4-diazepin-1-yl)-6-hydroxy-1 $H$-benzimidazole (6-hydroxyemedastine), 1-(2-ethoxyethyl)-2-(hexahydro-4-methyl-5-oxo-1H-1, 4-diazepin-1-yl)-5-hydroxy-1 $H^{-}$-benzimidazole (5-hydroxy-5' -oxoemedatine) and 1-(2-ethoxyethyl)-2-(hexahydro4-methyl-5-oxo-1H-1,4-diazepin-1-yl)-6-hydroxy-1H-benzimidazole (6-hydroxy-5'-oxoemedastine), were all synthesized at Pharmaceuticals Research Center of Kanebo, Ltd ${ }^{15)}$. The other reagents of special grade were purchased from Wako Pure Chemical Industries, Ltd. (Osaka, Japan).

Human Urine after Oral Administration of Emedastine Difumarate - The urine samples used were obtained through the phase I study of emedastine difumarate ${ }^{14)}$. Five healthy male volunteers nonfasted were orally administered emedastine difumarate at doses of 2 or $8 \mathrm{mg}$ as sustained release capsules which were prepared at Pharmaceuticals Research Center of Kanebo, Ltd. The urine was then collected periodically for up to 24 h. The samples were stored at $-20^{\circ} \mathrm{C}$ until analysis.

Extraction of Unconjugated and Conjugated Metabolites in Urine-Unconjugated metabolites: A $100 \mathrm{~m} l$ of urine was adjusted to about pH10 by adding a few drops of $5 \mathrm{~N}$ sodium hydroxide and extracted with three $300 \mathrm{~m} l$ portions of chroloform. The organic layer was separated and evaporated to dryness under a stream of nitrogen at about 40 ${ }^{\circ} \mathrm{C}$. The residue was dissolved in $10 \mathrm{~m} l$ of $0.1 \mathrm{~N}$ hydrochloric acid, and the mixture was washed three times with $25 \mathrm{~m} l$ of chloroform. The aqueous layer was adjusted to about $\mathrm{pH} 10$ by adding about $0.2 \mathrm{~m} l$ of $5 \mathrm{~N}$ sodium hydroxide, and emedastine and the unconjugated metabolites in the mixture were extracted with three $30 \mathrm{~m} l$ portions of chloroform. 
Conjugated metabolites: The aqueous layer obtained by first extraction with chloroform as above was concentrated by a rotary evaporater at about $40^{\circ} \mathrm{C}$ until chloroform remained was removed, and conc. hydrochloric acid was added to give a final concentration of $3 \mathrm{~N}$, followed by the hydrolysis of conjugated metabolites in boiling water for $2 \mathrm{~h}$. After hydrolysis $5 \mathrm{~N}$ sodium hydroxide was added little by little to the mixture, which was kept cooling in ice-cold water, to give a final $\mathrm{pH}$ of about 10 . The hydrolyzed products obtained from the conjugated metabolites in the mixture were separated by extraction and futher back-extracted in the same manner as above. The unconjugated metabolites and hydrolyzed products of the conjugated metabolites were analyzed by the GC method individually.

Determination of emedastine in Urine-Emedastine in urine was determined by the GC method as described in the previous report ${ }^{10)}$.

Determination of Demethylemedastine in Urine - Demethylemedastine in urine was determined after dansyl derivatization by the high-performance liquid chromatography combined with a fluoresence detector as described in the previous report ${ }^{12)}$.

Determination of 5-Hydroxy- and 6-Hydroxyemedastine in Urine- Unconjugated fraction : A $1 \mathrm{~m} l$ sample of urine was adjusted to about pH10 by adding a few drops of 0.2 $N$ sodium hydroxide and $0.5 \mathrm{~m} l$ of $0.5 \mathrm{M}$ phosphate buffer ( $\mathrm{pH} 10$ ), followed by extraction with $6 \mathrm{~m} l$ of chloroform. Five $\mathrm{m} l$ of the organic layer was separated, and after addition of 50ng of the internal standard, 1-(2-butoxyethyl)-2-(hexahydro-4-methyl-1H-1,4-diazepin-1-yl)-1H-benzimidazole difumarate, evaporated to dryness under a stream of nitrogen at about $40^{\circ} \mathrm{C}$. The residue was dissolved in methanol-25 28\% ammonia water $(50: 1$, $\mathrm{v} / \mathrm{v}$ ), and a $1 \mu l$ aliquot was subjected to GC. Conjugated fraction : A $0.6 \mathrm{~m} l$ of sample of urine was mixed with $0.2 \mathrm{~m} l$ of conc. hydrochloric acid, followed by hydrolysis in boiling water for $2 \mathrm{~h}$. To the reaction mixture was added sodium hydroxide to give a final $\mathrm{pH}$ of about 10 and $0.5 \mathrm{~m} l$ of $0.5 \mathrm{M}$ phosphate buffer $(\mathrm{pH} 10)$, and the extraction was performed according to the above procedure. Concentrations of the conjugated metabolites were calculated by subtracting those of the unconjugated ones from total concentrations.

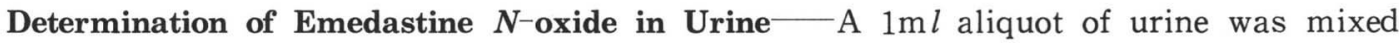
with $1 \mathrm{~m} l$ of $0.2 N$ sodium hydroxide and emedastine in the mixture was removed by extraction with three $6 \mathrm{~m} l$ portions of benzene. The mixture was subsequently extracted with three $6 \mathrm{ml}$ portions of chloroform, and after addition of 50ng of the internal standard, 1 (2-ethoxyethyl)-2-(4-methyl-piperazinyl)-1H-benzimidazole $3 / 2$ fumarate into the organic layer collected, evaporated to dryness under a stream of nitrogen at about $40^{\circ} \mathrm{C}$. The residue was dissolved in methanol-25 28\% ammonia water $(50: 1, \mathrm{v} / \mathrm{v})$, and a $1 \mu l$ aliquot was subjected to GC.

Determination of $5-\mathrm{Hydroxy}{ }^{-}$and 6-Hydroxy ${ }^{-5}{ }^{\prime}$-oxoemedastine in Urine -5 -Hydroxyand 6-hydroxy-5'-oxoemedastine were determined by the same method as 5-hydroxy- 
and 6-hydroxyemedastine were done, except for using cinnarizine for an internal standard.

GC Method - The capillary gas chromatographic method with a nitrogen-sensitive detector described in the previous report ${ }^{10)}$ was used. But the column used was a flexible fused silica capillary column coated with OV-1701 $(25 \mathrm{~m} \times 0.2 \mathrm{~mm}$ i.d., Shimadzu Co., Kyoto, Japan) for the determination of 5-hydroxy - and 6-hydroxyemedastine and emedastine $N$-oxide. The flexible fused silica capillary column coated with $\mathrm{OV}-101(25 \mathrm{~m} \times 0.2$ mm i.d., Shimadzu) was used for the other experiments.

\section{Results}

\section{Separation of Emedastine and Its Metabolites Synthesized}

The gas chromatogram of emedastine and its metabolites separated by GC with OV101 capillary column is shown in Fig. 2. The retention time of emedastine was about 7.7 min and identical with those of demethylemedastine and emedastine $N$-oxide. On the other hand, desethylemedastine, 5-hydroxy- and 6-hydroxyemedastine, and 5-hydroxyand 6-hydroxy-5'-oxoemedastine were completely separated with each other, and those retention times were about $8.3,14.6,13.6,29.0$ and $27.6 \mathrm{~min}$, respectively.

\section{Separation of Emedastine and Its Metabolites in Urine}

The typical gas chromatograms obtained from human urine before and after oral adm-

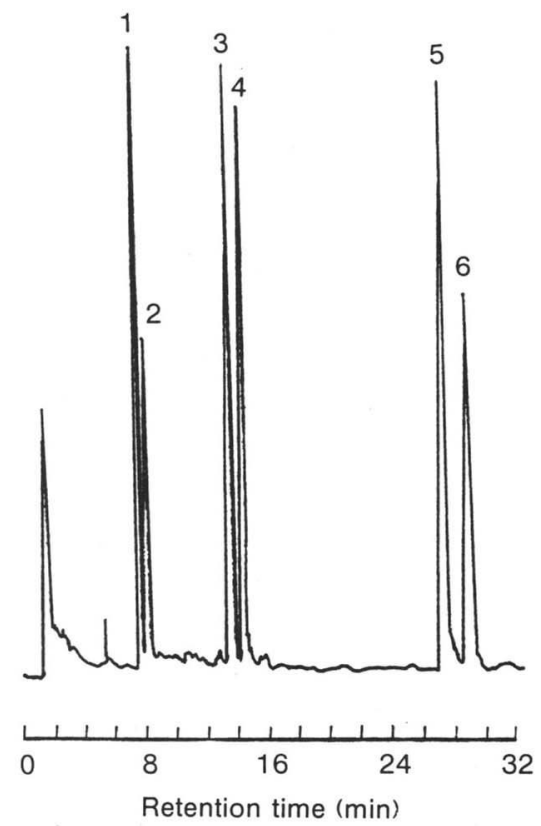

Fig. 2 Gas chromatogram of emedastine and its metabolites synthesized

1, emedastine, demethylemedastine and emedastine- $\mathrm{N}^{-}$-oxide ;

2, desethyemedastine; 3, 6-hydroxyemedastine ;

4, 5-hydroxyemedastine; 5, 6-hydroxy-5'-oxoemedastine ;

6, 5-hydroxy-5'-oxoemedastine 

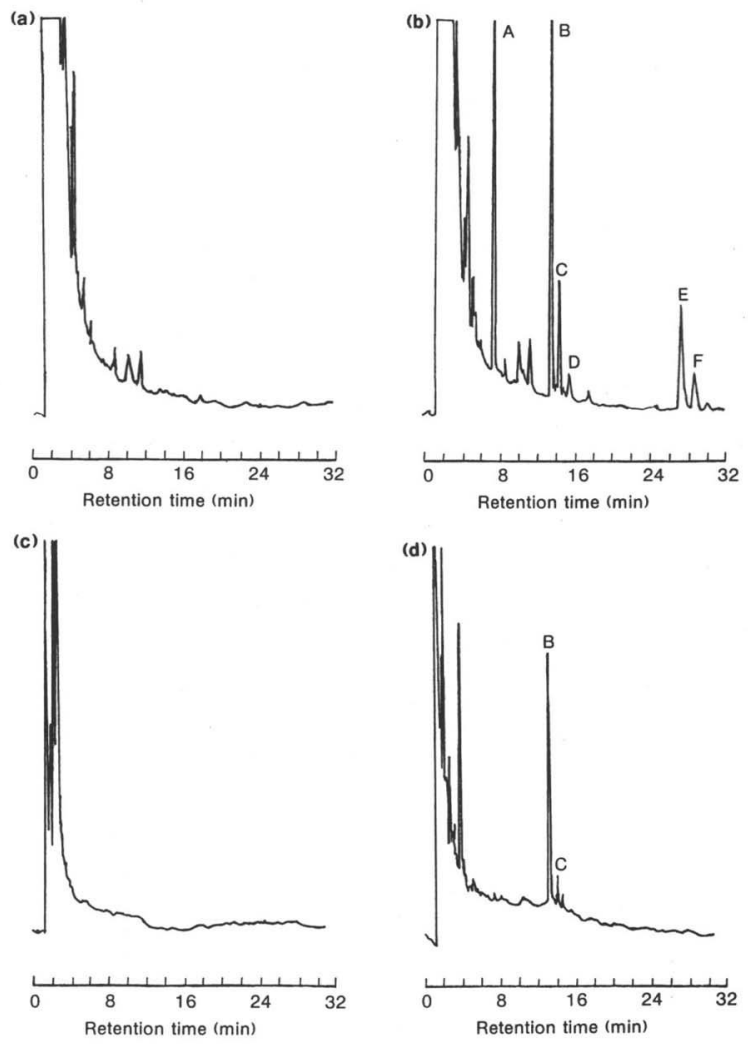

Fig. 3 Gas chromatograms of blank urine and urine after oral administration of emedastine difumarate at a dose of $8 \mathrm{mg}$ in human

(a) unconjugated fraction (blank urine)

(b) unconjugated fraction (urine after oral dosing)

(c) conjugated fraction (blank urine)

(d) conjugated fraction (urine after oral dosing)

See the text for details of peaks A, B, C, D, E and F.

inistration of emedastine difumarate at a dose of $8 \mathrm{mg}$ are shown in Fig. 3. In unconjugated fraction, 6 sharp peaks (peaks A, B, C, D,E and F), which were not observed in blank urine, were observed, and the retention time of peak $\mathrm{A}$ was identical to those of emedastine, demethylemedastine and emedastine $N$-oxide, peak B was to 6 -hydroxyemedastine, peak $\mathrm{C}$ was to 5-hydroxyemedastine, peak $\mathrm{E}$ was to 6 -hydroxy-5'-oxoemedastine and peak $\mathrm{F}$ was to 5 -hydroxy-5'-oxoemedastine, respectively. Desethylemedastine was not detected. The retention time of peak $\mathrm{D}$ was not identical to those of any authentic compounds tested. In conjugated fraction, 2 sharp peaks (peaks B and C), which were not observed in blank urine, were observed, and the retention times of peaks $\mathrm{B}$ and $\mathrm{C}$ were identical to those of 6-hydroxyemedastine and 5-hydroxyemedastine, respectively.

\section{Determination of Emedastine and Its Metabolites in Urine}

Emedastine and its metabolites in urine collected periodically for up to $24 \mathrm{~h}$ after oral administration of emedastine difumarate at a dose of $2 \mathrm{mg}$ were quantified. The result is shown in Fig. 4. The urinary concentration of demethylemedastine was below the detec- 


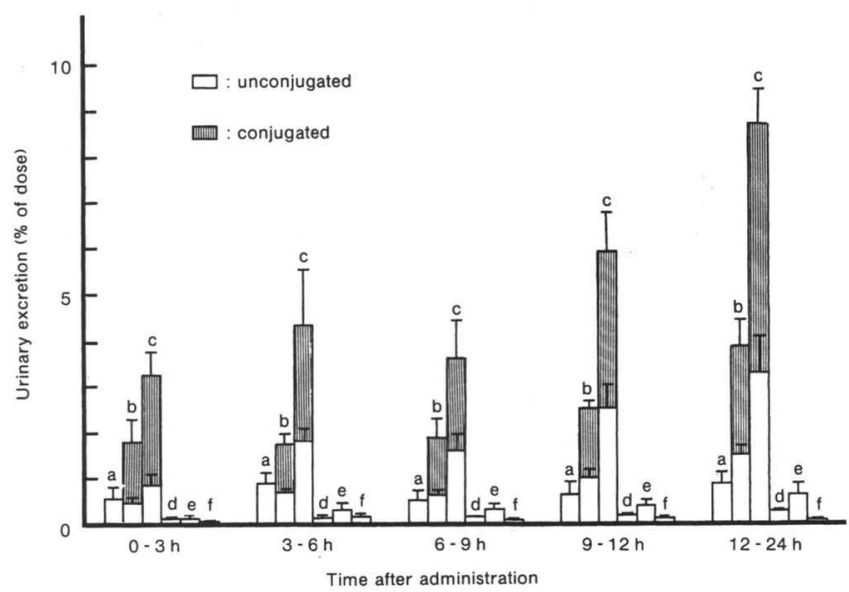

Fig. 4 Urinary excretion of emedastine and its metabolites for $24 \mathrm{~h}$ after oral administration of emedastine difumarate at a dose of $2 \mathrm{mg}$ in human Each data represents the mean of 5 subjects and the vertical bars represent the standard deviation of the mean.

a, emedastine; b, 5-hydroxyemedastine ;

c, 6-hydroxyemedastine; d, 5-hydroxy-5'-oxoemedastime ;

e, 6-hydroxy-5'-oxoemedastine; f, emedastine $\mathrm{N}$-oxide

tion limit $(0.4 \mathrm{ng} / \mathrm{m} l)^{12)}$ at any times after oral administration. 6-Hydroxyemedastine and its conjugated metabolite were most extensively excreted, and those cumulative urinary excretion ratios for $24 \mathrm{~h}$ were 10.0 and $16.0 \%$ of dose, respectively. The excretion ratios of 5-hydroxyemedastine, its conjugated metabolite and emedastine were 4.2,7.5 and 3.6 $\%$ of dose, respectively. The excretion of 5 -hydroxy- and 6 -hydroxy-5'-oxoemedastine and emedastine $N$-oxide were relatively low with the excretion ratios of $0.8,1.6$ and 0.4 $\%$ of dose, respectively. On the other hand, while the urinary excretion rates of emedastine and emedastine $N$-oxide were the highest at 3 to $6 \mathrm{~h}$ after oral administration, those of the other metabolites measured were at 9 to $12 \mathrm{~h}$.

\section{Discussion}

The metabolism of emedastine difumarate after oral administration in human was studied. The gas chromatogram obtained from the urine after oral administration of emedastine difumarate suggested the exsistence of 5-hydroxy- and 6-hydroxyemedastine, and 5-hydroxy- and 6-hydroxy-5'-oxoemedastine. Emedastine, demethylemedastine and emedastine $\mathrm{N}$-oxide had the same retention time when those were injected into the OV101 column. Therefore demethylemedastine in urine was selectively determined after dansyl derivatization by the high-performance liquid chromatography combined with a fluoresence detector, and the results showed that the concentration of demethylemedastine in urine was below the detection limit $\left(0.4 \mathrm{ng} / \mathrm{m} l^{12)}\right)$. On the other hand, emedastine $N^{-}$ oxide was selectively separateted from emedastine by solvent extraction and using the OV-101 column. And it was shown that emedastine $N$-oxide was present by about $10 \%$ of the amount of emedastine.

We have already reported that demethylemedastine and 5-hydroxyemedastine which 
possessed the pharmacological activities were little present in human plasma ${ }^{13)}$. In the present study, the amount of 5-hydroxyemedasrtine in human urine was comparable to that of emedastine, and conjugated 5-hydroxyemedastine was also present two times more than unconjugated one. The fact that 5-hydroxyemedastine was not detected in human plasma might be due to more rapid excretion and conjugation of 5 -hydroxyemedastine than the formation of 5-hydroxyemedastine from emedastine. We suggested in the previous report that the pharmacological activity, that is, the inhibitory effect on histamine-induced mortality in guinea pigs, was well correlated to the concentration of unchanged emedastine in plasma ${ }^{11)}$. As the pharmacologically active compound in human plasma was almost only unchanged emedastine, in human the antihistaminic and antiallergic activities might be correlated to the concentration of unchanged emedastine in plasma.

Metabolites which were produced by hydroxylation of benzimidazole ring and lactam formation of 1,4-diazepine ring, namely 5-hydroxy-5'-oxoemedastine and 6-hydroxy-5'oxoemedastine, were found in human urine. The lactams were found in the compounds having piperazine, piperizine, pirorizine and morphorine ring ${ }^{16 \sim 19)}$, but not reported in those having 1,4-diazepine ring. In mydocalm and TZU-0460 having piperizine ring, it was reported that the lactams were formed more easily in animals rather than in hu$\operatorname{man}^{17)}$. On the other hand, in emedastine having 1,4-diazepine ring the both lactams were more formed in human than in rats $(0.13 \%$ of dose), guinea pigs (below the detection limit) and dogs (below the detection limit).

In our previous report ${ }^{2}$, the experiment on the biliary and urinary excretion in rats showed that emedastine difumarate was almost completely absorbed from the intestinal tract. In rats, guinea pigs and dogs, cumulative urinary excretion ratios of radioactivity for $24 \mathrm{~h}$ after oral administration of ${ }^{14} \mathrm{C}$-emedastine difumarate which were $29.5 \pm 5.2$ (mean \pm S. D., $\mathrm{n}=3), 37.3 \pm 3.7(\mathrm{n}=4)$ and $59.1 \pm 4.7(\mathrm{n}=3) \%$ of dose, respectively, were similar to those after intravenous administration which were $37.5 \pm 4.5(n=3), 45.3$ $\pm 13.3(\mathrm{n}=4)$ and $61.6 \pm 8.2(\mathrm{n}=3) \%$ of dose, respectively ${ }^{2,20)}$. From these data it was presumed that emedastine difumarate was well absorbed from intestinal tract in 3 experimental animals ${ }^{2,20)}$. In human, the sum of urinary excretion ratio of emedastine and its metabolites determined for $24 \mathrm{~h}$ after oral administration of emedastine difumarate was $44.1 \%$ of dose, and thus there was not so large difference in urinary excretion between human and animals. So absorption of emedastine difumarate might be also well in human as well as in animals.

The extent of bioavailability $(F)$ of emedastine after oral administration in guinea pigs was 0.495 and higher than that in rats $(0.036)$ and dogs $(0.052)^{4)}$. When absorption is complete and elimination is done only in the liver, $F$ after oral administration can be estimated by a following equation,

$$
F=Q /\left\{Q+(\text { dose }-U) / A U C \cdot R_{B}\right\}
$$

where $Q, U, A U C$ and $R$ represents the hepatic blood flow rate, extent of urinary excretion, area under the plasma concentration-time curve and blood-to-plasma concentration ratio, respectively. The value of $R$ for emedastine in human determined by in vitro experiment as shown in previous report8) was 0.71 (unpublished data). The reported value 
of $Q$ in human is $21 \mathrm{ml} / \mathrm{min} / \mathrm{kg}$ of body weight ${ }^{21)}$. The values of $U$ and $A U C$ at a dose of $2 \mathrm{mg} / \mathrm{kg}$ in human (mean body weight, $67.4 \mathrm{~kg}$ ) were $40.5 \mu \mathrm{g}$ and $15.7 \mathrm{ng} \cdot \mathrm{h} / \mathrm{ml}$, respectively ${ }^{14)}$. Absorption of emedastine difumarate was well in 3 experimental animals as above, and emedastine was metabolized mainly in the liver in rats as shown in previous report $^{7)}$. If absorption ratio and eliminating organ for emedastine in human were similar to those in animals, the value of $\mathrm{F}$ calculated in human was 0.46 and comparable to that in guinea pigs. Moreover urinary excretion of emedastine in guinea pigs $(3.67 \%$ of dose $)^{6)}$ was more than that in rats $(0.10 \% \text { of dose })^{6)}$ and $\operatorname{dogs}(0.75 \% \text { of dose })^{20)}$. Urinary excretion of emedastine in human was $3.6 \%$ of dose, and similar to that in guinea pigs. These results show that the extent of bioavailability in human may be similar to that in guinea pigs rather than in rats and dogs.

We have already reported that the main pathways of biotransformation of emedastine difumarate in animals were: (a) aromatic hydroxylation in the benzimidazole ring, (b) $\mathrm{N}$ oxidation and $N$-demethylation in the 1,4-diazepine ring, (c) $\alpha$-carbon oxidation (lactam formation) in the 1,4-diazepine ring and (d) $O$-deethylation in the $N$-ethoxyethyl side cha$i^{5 \sim 7}$. There were pronounced interspecies differences in metabolism, that is, the main metabolic pathways were hydroxylation in the benzimidazole ring in rats, $N$-oxidation in the 1,4-diazepine ring in guinea pigs, and both hydroxylation and $N$-oxidation in dogs $s^{5 \sim 7}$. In human the main metabolites were 5-hydroxy- and 6-hydroxyemedastine. 5Hydroxy-and 6-hydroxy-5'-oxoemedastine, and emedastine $N$-oxide were also found but slightly. Therefore, metabolic pattern in human might be similar to that in rats.

\section{Acknowledgment}

We are grateful to Dr. S. Nakajima and his co-workers (Fourth Department of Internal Medicine, Kinki University) for supplying the human urine samples obtained from phase I study of emedastine difumarate.

\section{References}

1) Fukuda, T., Morimoto, Y., Iemura, R., Kawashima, T., Tsukamoto, G., Ito, K. : Effect of 1-(2-ethoxyethyl)-2-(4-methyl-1-homopiperazinyl) benzimidazole difumarate (K B-2413), a new antiallergic, on chemical mediators. Arzneim.-Forsch./Drug Res., $34:$ 801-805 (1984).

Fukuda, T., Saito, T., Tajima, S., Shimohara, K., Ito, K. : Antiallergic effect of 1-(2-ethoxyethyl)-2-(4-methyl-1-homopiperazinyl) benzimidazole difumarate (K B-2413). ibid., $34: 805-810$ (1984).

Fukuda, T., Saito, T., Ito, K. : Antiasthmatic effect of 1-(2-ethoxyethyl)2-(4- methyl-1-homopiperazinyl) benzimidazole difumarate (KB-2413), a new antiallergic. ibid., $34: 811-815$ (1984).

Fukuda, T., Saito, T., Yoshidomi, M., Ito, K. : Influence of 1-(2-ethoxyethyl)-2-(4-methyl-1-homopiperazinyl) benzimidazole difumarate (KB2413), a new antiallergic, on ciliary movement. ibid., $34: 816-818$ (1984).

2) Sakai, T., Takahashi, H., Hamada, T., A wata, N., Watanabe, J. : The biological fate of 1-(2-ethoxyethyl)-2-(4-methyl-1-homopiperazinyl) benzimidazole difumarate (KB-2413) I, absorption and excretion after oral administration to rats and guinea pigs. Xenobio. Metabol. and Dispos., 2: 123-131 (1987).

3) Sakai, T., Takahashi, H., Hamada, T., Awata, N., Watanabe, J. : The biological fate of 1-(2-ethoxyethyl)-2-(4-methyl-1-homopiperazinyl) ben- 
zimidazole difumarate (KB-2413) II, distribution after single and multiple oral administration to rats. Xenobio. Metabol. and Dispos., 2 : 133-145 (1987).

4) Sakai, T., Hamada, T., Awata, N., Watanabe, J. : Pharmacokinetics of an antiallergic agent, 1-(2-ethoxyethyl)-2-(hexahydro-4-methyl-1 $\mathrm{H}_{-1}-$ 4- $^{-}$ diazepin-1-yl)- $1 H$-benzimidazole difumarate (KG-2413) after oral administration: interspecies differences in rats, guinea pigs and dogs. J. Pharmacobio-Dyn., 12 : 530-536 (1989).

5) Awata, N., Takahashi, H., Noumi, K., Sakai, T., Hamada, T. : Identification of the metabolites of an antiallergic agent, 1-(2-ethoxyethyl)-2(hexahydro-4-methyl-1 $H$-1, 4-diazepin-1-yl)- $1 H$-benzimidazole difumarate (KG-2413), in rats. Yakugaku Zasshi, 109:318-328 (1989).

6) Wada, Y., Takahashi, H., Hamada, T., Sakai, T., Kawashima, T., Awata, N. : Metabolism of an antiallergic agent, 1-(2-ethoxyethyl)-2-(hexahydro-

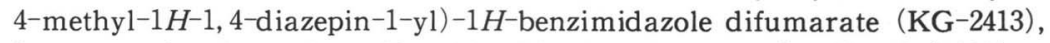
in rats and guinea pigs. Xenobio. Metabol. Dispos., $4: 459-470$ (1989).

7) Wada, Y., Hamada, T., Kawashima, T., Awata, N. : In vitro metabolism of an antiallergic agent, emedastine difumarate, in rats and guinea pigs. Yakugaku Zasshi, 110 : 40-48 (1990).

8) Sakai, T., Hamada, T., Awata, N., Watanabe, J. : Interspecies differences in pharmacokinetics of an antiallergic agent, 1-(2-ethoxyethyl)-2-(hexahydro-4-methyl-1,4-diazepin-1-yl) benzimidazole difumarate(KG-2413) after intravenous administration to rats, guinea pigs and dogs. Chem. Pharm. Bull., 37 : 753-756 (1989).

9) Sakai, T., Hamada, T., Awata, N., Watanabe, J. : Binding of 1-(2-ethoxyethyl)-2-(hexahydro-4-methyl-1 $H$-1,4-diazepin-1-yl) benzimidazole difumarate (KG-2413) to serum or plasma proteins in man, guinea pig and rat. J. Pharmacobio-Dyn., $11: 262-267$ (1988).

10) Hamada, T., Kadowaki, M., Nakamura,Y., Awata, N. : Determination of the antiallergic agent KB-2413 in plasma by means of capillary gas chromatography with a nitrogen-sensitive detector. Chem. Pharm. Bull., 34 : 1168-1171 (1986).

11) Hamada, T., Kadowaki, M., Awata, N. : Redioreceptor assay for a new antiallergic agent, 1-(2-ethoxyethyl)-2-(4-methyl-1-homopiperazinyl) benzimidazole difumarate (KB-2413), in plasma. Chem. Pharm. Bull., 35 : 3329-3335 (1987).

12) Hamada, T., Kawashima, T., Awata, N. : Cross-reactivities of active metabolites in the radioreceptor assay of an antiallergic agent, 1-(2-ethoxyethyl)-2-(hexahydro-4-methyl-1 $H$-1, 4-diazepin-1-yl)- $1 H$-benzimidazole difumarate (KG-2413). Yakugaku Zasshi, 109:474-479 (1989).

13) Hamada, T., Kawashima, T., Awata, N. : Selective and sensitive determination of an antiallergic agent, emedastine difumarate (KG-2413), in human plasma by the radioreceptor assay combined with a high-performance liquid chromatography. Yakugaku Zasshi, 109 : 749-754 (1989).

14) Nakajima, S., Tsuya, Y., Ohisi, M., Doi, Y., Yamazaki, K., Ohba, Y. : Phase I study of emedastine difumarate (KG-2413) (2) Single and consecutive administration studies using capusules containing sustaind release granules of KG-2413. Kiso to Rhinsho, 23 : 159-168 (1989).

15) Iemura, R., Hori, M., Ohtaka, H. : Syntheses of the metabolites of 1-(2ethoxyethyl)-2-(hyxahydro-4-methyl-1 $H-1$, 4-diazepin-1-yl)- $1 H$-benzimidazole difumarate (KG-2413) and related compounds. Chem. Pharm. Bull., 37 : 962-966 (1989).

16) Gau, W., Kurz, J., Petersen, U., Ploschke, H.J., Wuensche, C. : Isolation and structural elucidation of urinary metabolites of ciprofloxacin. Arzneim. -Forsch./Drug Res., 36 : 1545-1549 (1986).

17) Honma, S., Akutsu, R., Iwamura, S., Kawabe, Y., Tsukamoto, K. : Metabolic fate of 2 -acetoxy $-N-[3-[m-(1-$ piperidinylmethyl $)$ phenoxy $]$ propyl $]$ 
acetamide hydrochloride (TZU-0460), a new $\mathrm{H}_{2}-$ receptor antagonist(8) the metabolism in man, Pharmacometrics, $30: 555-563$ (1985).

18) Pitts, J.E., Bruce, R.B., Forehand, J.B. : Identification of doxapram metabolites using high pressure ion exchange chromatography and mass spectroscopy, Xenobiotica, 3:73-83 (1973).

19) Tatsumi, K., Kitamura, S., Yoshimura, H. : The metabolism of phenyl $o^{-}$ (2- $N$-morpholinoethoxy) phenyl ether hydrochloride in the rabbit and rat, Xenobiotica, 5 : 377-388 (1975).

20) Wada, Y., Hamada, T., Sakai, T., Kawashima, T., Awata, N. : Absorption, metabolism and excretion of an antiallergic agent, 1-(2-ethoxyethyl)2-(hexahydro-4-methyl- $1 H^{-1}, 4$-diazepin-1-yl)- $1 H$-benzimidazole difumarate(KG-2413), in dogs. Xenobio. Metabol. and Dispos., $4: 471-480$ (1989).

21) Hanano, M., Umemura, K., Iga, T. : "Applied pharmacokinetics-Theory and experiments"», Soft Science, Inc., Tokyo, 433-436 (1985). 